\title{
El deporte es nuestro. Experiencias de construcción de instalaciones deportivas en tiempos de crisis
}

\author{
Dr. Gaspar Maza Gutiérrez
}

La alienación del espectador a favor del objeto contemplado (que es el resultado de su propia actividad inconsciente) se expresa de este modo: cuanto más contempla, menos vive; cuanto más acepta reconocerse en las imágenes dominantes de la necesidad, menos comprende su propia existencia y su propio deseo. La exterioridad del espectáculo en relación con el hombre activo se hace manifiesta en el hecho de que sus propios gestos dejan de ser suyos para convertirse en los gestos de otro que los representa para él (Debord, Guy: La sociedad del espectáculo, p. 49).

"El barrio es nuestro" fue uno de los eslóganes más populares y significativos de las luchas vecinales de los movimientos sociales de los años setenta y ochenta. Los logros vecinales, asociados al desarrollo del estado de bienestar, se centraron en dotaciones de instalaciones básicas (agua, luz, aceras, iluminación...) a las que posteriormente se añadieron centros cívicos, bibliotecas, polideportivos... A la vez que se conseguían recursos se fue organizando su gestión a través de empresas especializadas (concesionarias, gestores, etc.). En este marco se generó una zonificación, de tal manera que la práctica deportiva se espacializó y se concentró en torno a zonas deportivas, de la misma forma que las industrias se concentraron en polígonos industriales.

A nivel simbólico, el deporte, representado por los clubes más exitosos, acaparó toda la atención y los sentimientos de los seguidores de ciudades como Madrid, Barcelona, Bilbao... Los grandes clubes de fútbol monopolizaron los sentimientos y las fidelidades de los vecinos, antes radicados en sus clubes de barrio y en sus ídolos locales. La televisión y la radio, por su parte, se encargaron de ofrecernos un consumo deportivo más variado y mejor servido. La práctica deportiva se especializó y se espectacularizó. 
Entrados ya en el siglo xxi se empieza a comprobar, a través de estudios y encuestas como las de los hábitos deportivos del año 2010, ${ }^{1}$ la aparición de cambios significativos en las actitudes que nos indican el desarrollo de un tipo de deporte más participativo, más lúdico y también más integral. Señales de ello son, por ejemplo, el éxito de las carreras populares, las campañas de deporte para todos, el incremento de personas que hacen deporte fuera de las instalaciones regladas, el aumento de personas que practican un deporte por distracción para hacer amistades o, simplemente, para estar en forma... Finalmente, la crisis económica empieza a hacer notar sus consecuencias más evidentes a partir del año 2010-2011, en que deja en el aire el desarrollo de muchas de nuestras mejores conquistas sociales y, entre ellas, también las deportivas.

Tres experiencias recientes de construcción de instalaciones lúdico-deportivas, con la colaboración y la participación ciudadana, nos muestran caminos nuevos y creativos que nos ofrecen interesantes oportunidades para la práctica deportiva autónoma y también un lugar idóneo donde ejercer la antropología. Si el barrio es aún de la gente, el deporte también tiene que seguir siéndolo, y con ese objetivo participamos en la producción de tres experiencias premiadas tras la celebración de la primera y la segunda convocatoria "Deporte, creatividad e inclusión social 2010-2011",2 organizado conjuntamente por el Consejo Superior de Deportes y el colectivo de arte contemporáneo Idensitat dentro del programa iD SPORT.

La primera de ellas se llevó a cabo en la plaza de la Cebada (Madrid 2011). En un solar en desuso, unos vecinos y unas asociaciones inquietos, encabezados por el colectivo Todo por la Praxis, consiguieron la recuperación de un espacio para el deporte, al que posteriormente dotaron de más instalaciones como vestuario, gradas y porterías que se autoconstruyeron a través de diferentes talleres participativos organizados en diferentes fines de semana.

La segunda iniciativa se sitúa en el pueblo de Arbúcies (Girona, 2012), donde se construyó un skatepark a iniciativa de los jóvenes del pueblo, ayudados por una asociación de skaters y el grupo de arquitectos Straddle3. La novedad en este proyecto fue el uso de materiales reciclados, obtenidos de la construc-

1. García Ferrando, M. y Llopis, R. (2011): “Ideal democrático y bienestar personal”, Encuesta sobre los hábitos deportivos en España 2010. Consejo Superior de Deportes, CIS. <http://www.csd.gob.es/csd/estaticos/dep-soc/encuesta-habitos-deportivos2010.pdf>

2. <http://www.planamasd.com/programas/intervencion-urbana/medidas/convocatoria-de-proyectos-dedeporte-creatividad-e-inclusion-s $>$ 
ción de una línea de metro y de una obra de infraestructura cerca del municipio. La experiencia de trabajo conjunto (jóvenes, skaters, arquitectos, técnicos municipales, diseñadores, antropólogos...) resultó ser un verdadero ejemplo de urbanismo emergente donde la ciudadanía pudo intervenir en la planificación de sus instalaciones deportivas.

La tercera iniciativa se sitúa en Errenteria (Guipúzcoa, 2012), donde el colectivo de arquitectos $\mathrm{M}$-etxea creó una instalación en forma de gusano a medio camino entre el mobiliario urbano y un equipamiento deportivo. Una estructura ligera que se usó para el deporte y la recuperación de un solar hasta ese momento contaminado. La colocación de esta infraestructura y su gestión vinieron acompañadas de la adecuación del entorno, que quedó mejorado tras retirarse la estructura. De este modo la infraestructura móvil funcionó como activador urbano y sus efectos fueron más allá del tiempo que estuvo instalada.

¿Cuáles son algunas de las lecciones que nos muestran estas tres experiencias? En primer lugar, que el deporte nos puede ofrecer oportunidades interesantes para la participación ciudadana en períodos tan necesitados de nuevas iniciativas como el actual. En los tres ejemplos vemos cómo los ciudadanos han vuelto a construir sus propias instalaciones deportivas. Esto ha servido, además, para poner en marcha diferentes tipos de procesos participativos y, a su vez, para generar redes de intercambio y de conocimiento nuevas.

Estas experiencias también demuestran que el deporte puede ser una potente herramienta de intervención urbana a modo de acupuntura, la cual, aunque humilde en sus pretensiones, ayuda a mejorar la ciudad sin la necesidad de grandes inversiones ni de organizar eventos especiales. El deporte se convirtió también en una reivindicación del derecho a la ciudad y a unos espacios lúdicos y deportivos construidos por y a medida de los propios usuarios, frente a unos espacios públicos y deportivos cada vez más diseñados y más predeterminados y rígidos en todas sus funciones.

La antropología, en su conexión con el deporte, el arte, el diseño o la arquitectura, ha entrado también en un campo muy interesante de interacciones y de procesos reflexivos diferentes.

Así, por ejemplo, en estas acciones los antropólogos hemos participado sentando criterios y bases para el concurso de experiencias e investigando los contextos sociales en los que vecinos, artistas, arquitectos y diseñadores planificaron posteriormente sus intervenciones. También participamos en la construc- 
ción física de las instalaciones, así como orientando los proyectos para intentar que respondan a las necesidades sociales planteadas en cada caso. Finalmente, también participamos en la producción de vídeos ${ }^{3}$ y diferentes artículos ${ }^{4}$ que han ayudado a documentar tales proyectos y, esperamos, también a difundirlos.

3. <http://idensitat.net $/$ index.php?option $=$ com_content\&view $=$ category $\&$ layout $=$ blog\&id $=112 \&$ Item id $=190>$

4. Maza, G. (2013): “IDENSITAT: A Hybrid Anthropology of Identity, Creativity, and Intervention in Public Spaces", American Anthropologist, vol. 115, mayo 2013. 